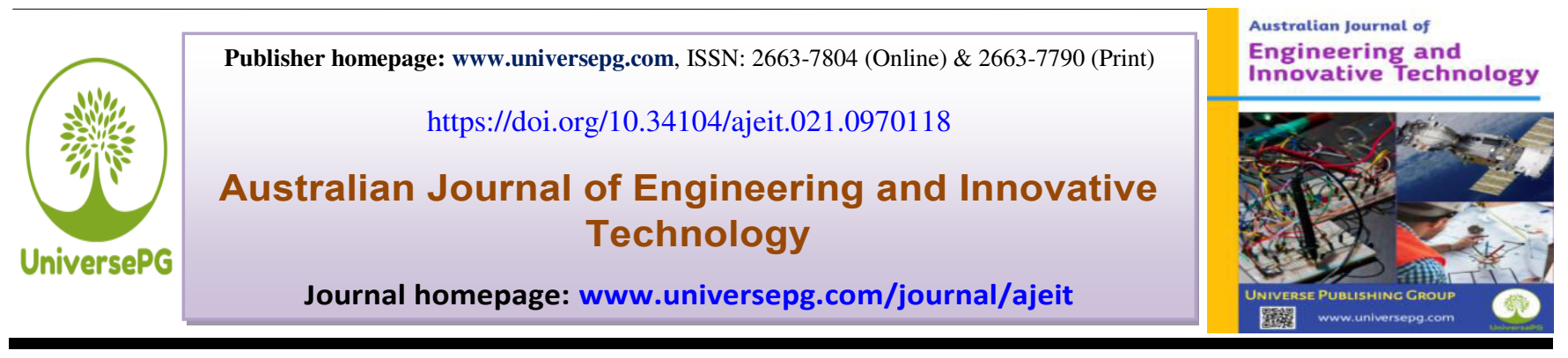

\title{
A Survey on an Intelligent System for Persons with Visual Disabilities
}

\author{
Md. Khaled Hassan ${ }^{1}$, Md. Rakibul Hassan ${ }^{1}$, M.M. Tanvir Ahmed ${ }^{1}$, Md. Sayeed Ahmed Sabbir ${ }^{1}$, Md. \\ Sabbir Ahmed ${ }^{1}$, and Milon Biswas ${ }^{1}$ * \\ ${ }^{1}$ Department of Computer Science and Engineering, Bangladesh University of Business and Technology (BUBT), Rupnagar \\ R/A, Mirpur-2, Dhaka-1216, Bangladesh. \\ *Correspondence: milonbiswas4702@gmail.com (Milon Biswas, Assistant Professor, Department of Computer Science and \\ Engineering, Bangladesh University of Business and Technology (BUBT), Dhaka-1216, Bangladesh).
}

\begin{abstract}
According to the World Health Organization (WHO), At least 2.2 billion individuals worldwide have near or far vision impairment out of 7.9 billion populations. In at least 1 billion cases, or about half of them, vision impairment might have been prevented or is currently untreated. The primary causes of vision impairment and loss are uncorrected errors and eye disorders. The majority of persons over the age of Fifty have visual impairment or blindness. Visual impairment or visual misfortunes are two terms that might be used to describe visual handicaps. This impairment makes it difficult for them to go about their daily activities such as shopping, strolling, mingling, and driving. The white stick is regarded as a symbol of opportunity, liberty, and security. In this paper, we attempted to discuss a comprehensive study of all the equipment and systems related to the simplification of visually impaired people's daily lives. Those devices can be portable or wearable or could be a system to detect objects. The emphasis was on the striking characteristics of that equipment, as well as the analysis was conducted predicated on a few variables such as power usage, mass, economics, and client. The aim was always to lay the groundwork for future researchers in the area by developing a handheld device or an efficient algorithm to protect visually impaired people.
\end{abstract}

Keywords: Visual disabilities, Blind stick, Deep learning, Machine learning, GPS, and Survey.

\section{INTRODUCTION:}

Visual insufficiency suggests the weakness of visual knowledge because of physiological or neurological components. Many outwardly hindered people have to bother keeping a real circadian musicality on account of the requirement for visual commitment to their psyches. In one's life exploring from one spot to another is perhaps the most significant and principal capacity. Outwardly tested individuals face this issue on an everyday premise. Many visually impaired individuals are reliant upon others for their route. To be sorted as visually impaired, there is an all-out loss of UniversePG I www.universepg.com vision. Visual inadequacy can't be helped by direct visual aids, for instance, glasses. For the indigents, visual lack is a hindrance. Along these lines, this paper propels a system to help the ostensibly tried. The assistor is a contraption that is an inert kind of vigilant stick that revolves around supporting the apparently incited people to move around, beginning with one spot then onto the following without worrying about anything. The ultrasonic sensors are used to determine how far away the articles are from the individual, and the image sensor precisely determines what those items are? The ultrasonic sensors 
are used to determine how far away the articles are from the individual, and the image sensor precisely determines what those items are. The data from the sensors is delivered to the Smartphone via Bluetooth communication. The stick's flexibility is provided by servo engine. The equipment parts are connected to the clever contraption through a microcontroller.

\section{Background}

This section covers the basic background facts about the topic, as well as the problems and challenges faced by visually impaired persons.

\section{Basic details}

A visual Substitution is a method for the visually impaired in which a picture is taken with a camera, data is produced, and the result is delivered to the customer in a non-visual format such as hearable mode, vibratory mode, or a combination of both. One of the significant incapacities looked at by outwardly tested individuals is Visual Impairment. The individual can't perceive the environmental factors nor is ready to feel the environmental factors because of an absence of eye vision. The primary point of this venture is to give visually impeded individuals an approach to take a gander at their environmental factors. This point is satisfied utilizing advancements like Artificial Intelligence, Machine Learning, Image Recognition, and Text Recognition. Visual Impairment leads to various difficulties in carrying out different tasks, including -

1) Basic day to day activities (Moving from one room to another, eating)

2) Traveling from one place to another for work, shopping, etc.

3) Reading, Writing, Social Interaction at different places.

The most popular solution to provide accessibility to Visually Impaired people by helping them in traveling from one place to another is the Smart Stick that uses a GPS module to track the user's location and various sensors and a microcontroller to alert users about the obstacles on the way (Subbiah et al., 2019). The problem with this system is that it works in less crowded areas and does not provide details about the surrounding. Another solution is the one that helps the visually impaired with reading using Speech SynUniversePG I www.universepg.com thesis Technology. It is an application that recognizes the text from a PDF document and reads it for the user (Sumathy et al., 2021). It uses a camera to take an image and convert it into a document. However, it requires an Internet connection and cannot work offline as it also provides Chabot functionalities such as light conversations.

Electronic Travel Aids (ETAs): It collects data from the environment and sends it to users using sensors such the Ultrasonic Sensor (Subbiah et al., 2019), Ultrasonic transducers (Nabiha et al., 2020), I.R. Sensor (Patel et al., 2018), LDR Sensor (Chiranjevulu et al., 2020), Accelerator Sensor (Yohannes et al., 2020), TCS3200 color sensor (Johari et al., 2020), Water sensor (Gbenga et al., 2017), and so on. These are the most typical visual substitutes employed by visually challenged people. According to National Research Council (Bledsoe et al., 1997), the rules for ETAs are:

1) Identifying obstacles near the client's body, from the beginning the head;

2) Finding things around the impediments;

3) Informing users of the distance between them and obstacles with the necessary directions;

4) Giving someone instructions on the surface's gap and roughness.

Electronic Orientation Aids (EOAs): It directs the individual on their way by offering directions or by using path signals like Smart Cane (Subbiah et al., 2019), Smart Glass (Mule et al., 2020), Cap (Rahman et al., 2021), and so on. These devices assist the user in navigating through and around the path. The EOA guidelines (Kammoun et al., 2021) are as follows:

1) Picking the ideal way by building up courses;

2) Estimating a user's approximate location by tracking the journey;

3) Directing the client by giving way markers and guidelines;

Position Locator Devices (PLDs): It finds the user's position and then locates them. This aids visually impaired people in locating themselves while traveling. Popular examples of Position Locator Devices are the Global Positioning System (GPS) (Subbiah et al., 2019; Chen et al., 2019; Suraj et al., 2019) and 
the Global System for Mobile Communication (GSM) (Subbiah et al., 2019).

\section{Issues and challenges}

Knowledge of the snags and issues that an outwardly disabled individual has in regular daily existence can help located individuals get what an individual with vision hindrance goes through. Natural Obstacles visually impaired individuals struggle to explore the outside. Going to jam-packed places like business sectors, train stations, etc., is much harder for them. Therefore, daze individuals look for help from relatives or assistive innovation. Social Obstacles Visually hindered individuals might encounter feelings of inadequacy since they can't take an interest in certain exercises that located individuals can. They additionally experience issues playing outside games. Innovative Obstacles When utilizing the web for study, joy, or business, dazzle people face difficulties. A blind individual will find it difficult to gather information from online pages. Despite the fact that numerous gadgets have been invented for the aim of extracting information; it is not widely used among blind people of all ages. Others Blind person's encounter numerous problems and differ from sighted people in a variety of ways. There are numerous other difficulties that blind people experience, including conducting home tasks, applying make-up, recognizing cash denominations, detecting obstacles, navigating, crossing the road, and so on.

\section{Existing Surveys}

The record (Elmannai et al., 2017) examines arrangements produced for outwardly weakened individuals up until the second from the last quarter of 2017. In a plain way, the general investigations, just as the advantages and negative marks of those arrangements, have been shown. Another investigation paper (Dakopoulos et al., 2009) characterized gadgets dependent on their provisions and execution boundaries. The advancement of material and sound-based assistive innovation for dazzle individuals has been point by point in the examination (Csapó et al., 2015) to give an outline of those arrangements.

The authors of (Proulx et al., 2016) took a gander at the exploration to check whether tactile replacement could consider online control of activity utilizing UniversePG I www.universepg.com visual data seen through strong or contact. The current situation with the craftsmanship for tangible replacement strategies to protest acknowledgment, restriction, and the route has likewise been tended to, just as the opportunities for these ways to deal with give a Meta modular social and neurological supporting for the online control of the activity. These survey papers aided in the comprehension of the method and flow of producing a survey study in this subject area. Although devices have been thoroughly documented and contrasted, little attention has been paid to the methods used in their development. In recent years, Artificial Intelligence-based products have been produced that were not included in prior survey reports.

\section{METHOLODOGY:}

To begin, we've compiled a list of terms that will be useful in looking for survey studies. For finding relevant publications, the Google Scholar web search engine was used in conjunction with IEEE and Research Gate databases. After year-by-year filtering, the papers were divided into two categories: survey and regular. The articles were then scrutinized, and data was retrieved in Excel/Word format for additional investigation. They were separating notes and related data into different files aided in the effective exploration and tracking of previous work. Each time another archive was considered, another watchword was added to the bunch of catch phrases. It was a clear system. The cycle we have embraced for making this outline paper has been portrayed in Fig 1.

\section{Assistive technology methods for visually challenged} As recently said, the need is to help the outwardly impeded by offering assistive innovation in their regular assignments, simplifying their life, more secure and more liberated. For quite a while, specialists have been dealing with creating this kind of arrangement that might help them in hindrance recognition, route, object I.D., transportation, etc. A couple of these gadgets have been analyzed widely in this segment to give an outline of the present status of the craftsmanship for this subject. As our studied papers were totally distributed between 2016-present so, we will talk about them year-wise. We gathered several projects and publications from a variety of Journals and search engines, including Google Scholar, Re- 
search Gate, and MDPI. The majority of the papers we surveyed were from IEEE and Springer periodicals. We attempted to locate the majority of the documents that are directly related to our convenience.

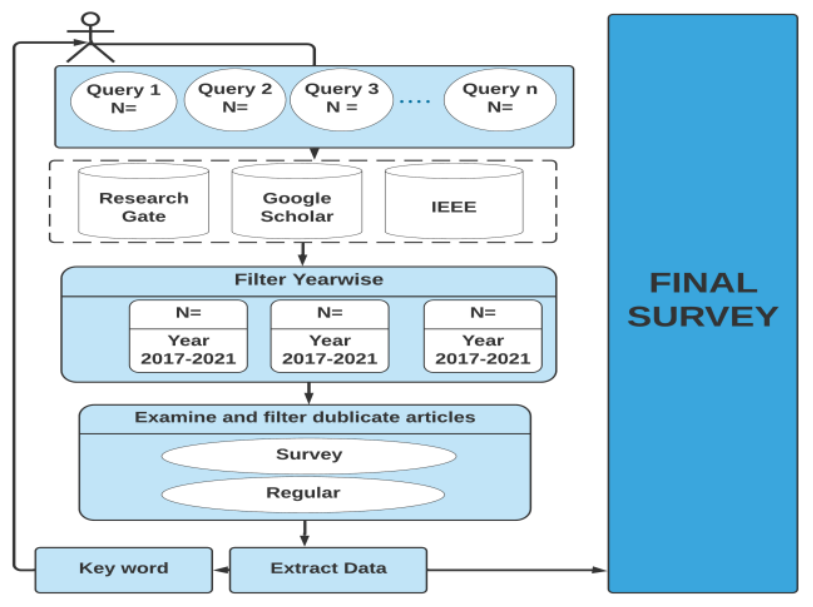

Fig 1: Flow of Survey.

Before 2017 - Here Author Krishnan et al. (2016) fostered their associate gadget, which is Sensor-Based and utilizing the SURF Model for the innovation of echolocation, picture preparing, and a route framework.

2017-2018 - Gbenga and group (Gbenga et al., 2017) didn't utilize any article identification innovation, including picture handling, yet they utilized a solid deterrent location framework utilizing Ultrasonic Sensors and a Microcontroller that can identify objects in the scope of $400 \mathrm{~cm}$ and inform the visually impaired individual with a bell.

2018-2019 - Patel et al. (2018) assembled a total framework for daze individuals, including a USB web-cam, an ultrasonic sensor, and an infrared sensor. For image processing, Raspberry pi is used. And Felix et al. (2018) used the Cloud Vision API, which encapsulates strong machine learning, which is utilized to analyze the image, collected, and the REST API is used to do so. The Google Cloud API design primarily makes use of a Chabot client for speech recognition and document translation. A Web-Hook is an HTTP callback: an HTTP POST that occurs when a direct notice is sent through HTTP POST in response to a request. When a request is made, a web application that uses Web Hook sends a message to the link. Then again, Parikh et al., (2018) utilized an Android cell phone with a camera and organization UniversePG I www.universepg.com association. For the current dataset, those creators used a different model to explain why Inception V3 has greater recognition rates than ResNet50 and VGG19.The recognition rate of ResNet50 was 94. $78 \%$, the recognition rate of VGG19 was $90.88 \%$, and the recognition rate of InceptionV3 was $96.4 \%$. Bashiri et al., (2018) used deep CNN predictive models to detect objects from 2D images to build this system and get $98 \%$ accuracy from it. Then, at that point, Jain et al. (2018) implemented their framework by utilizing Raspberry pi, a pi camera, ultrasonic Sensor OpenCV, and Python. They got input is perceived utilizing Google API. They distinguish objects utilizing Haar course classifiers and shadingbased item discovery procedures.

2019-2020 - An ultrasonic sensor is utilized to identify a hindrance by discharging recurrent sound waves towards an item by Subbiah et al. (2019). It's everything except a resonation or reflected sign to the authority part of the sensor while hitting the thing. The time is taken for releasing the sign and getting back the not set in stone from which distance of the article from the not really settled. Then again, Bhandari et al. (2021) utilized Primarily CNN structures for this cycle, with some additionally having capacities for fast and precision (i.e., SegNet, LeNet, YOLO calculations). Then, at that point at (Arora et al., 2019), Arora et al. proposed to assemble a model that performs constant item recognition utilizing picture division and a profound neural organization. The exactness of location is provoked by a discourse upgrade to the visually impaired individual who holds the gadget holder. It utilizes a blend of a solitary shot multi-box location casing and portable Net design. Kumar et al. (2019) proposed Faster RCNN with a profound neural organization and single-shot identifier (SSD) calculation with extra layers with a precision of more than $75 \%$. Their frameworks can recognize objects from any sort of camera, including a webcam. Hen et al. (2019) proposed a wise assistive framework for daze individuals that would incorporate wearable keen glasses, a clever strolling stick, a cell phone application, and an online data stage. Sadly, they didn't use any significant learning systems for seeing front pictures. The framework contains an infrared (I.R.) handset sensor module and a GPS 
framework with different modules. Bastomi et al. (2019) tested that the Convolutional Neural Net-work strategy is extremely successful in identifying an object and decide distance with a normal precision of 93.33\%. This proposed frame-work has a significant mistake with a worth of $6.1 \%$ and identifies just six items (human, table, seat, vehicle, bike, and cruiser) as indicated by the dataset. Suraj et al. (2019) zeroed in on distinguishing the nearest obstruction utilizing the sonar rule and thus produced vibrotactile criticism that alarms the client about the heading of the article. In their proposed model, three Ultrasonic sensors (Adraxx HC-SR04) are intended for location and two vibration engines for cautioning the client. It utilizes an ultrasonic sign of recurrence $40 \mathrm{KHz}$ to handle insights regarding the feeling, and this can be utilized to distinguish the presence of any article inside the scope of 0.02 to 4 meters around. They also rely on clearly incapacitated after using the GPS module, which detects the customer's present location, is cautious up to 30 meters, and communicates that information to a large number of emergency contacts via the GSM module, which includes a SIM card. HR-SO4 ultrasonic sensors, YOLO, and CNN, were proposed by Kumar et al. (2019) to recognize any check that lies within the sensor's range and choose its distance. This model is compact and lightweight to such an extent that it very well may be utilized inside and outside with no trouble. Around $56 \%$ gives a more extensive scope of conditions for hindrance recognition and grouping.

2020-2021 - Nabiha et al. (2020) made a pi camera on a raspberry pi that guides them through the climate utilizing TTS, a GPS module to cross the area utilizing a cell phone, and a sensor to recognize deterrents. Yohannes et al. (2020) utilized a few kinds of sensors like ultrasonic sensor, I.R. sensor, gas pedal sensor, and LDR sensor, which were answerable for developing the visually impaired stick.

Bhole et al. (2020) India is home to the world's biggest outwardly disabled populace. Another structure helps the outwardly weakened explore and know about their environmental factors. Beginning v3 models are prepared to perceive human countenances and money notes whenever identified by a solitary shot identifier. The yield from the structure would UniversePG I www.universepg.com then be able to be introduced to the outwardly hindered individual in the sound organization. Mule et al. (2020) proposed a framework basically centered on giving in-house object discovery, utilizing Raspberry pi three units, TensorFlow, OpenCV, and SSD lite Mobile Net V2. The framework computes the distance between the clients and items. It has shown exactness 0.85 and reviews 0.8 with a 2 -second deferral in creating sound yield. A sharp stick dependent upon Traffic Light Crossing (TLC) Algorithm has been proposed by Johari et al. (2020) for evidently attempted individuals. Later on, it is proposed that the stick be presented with voice insistence and a GPS organizing structure. It very well may be utilized by outwardly weakened individuals while strolling through streets and traffic signals. Moharkar et al. (2020) used the CNN method to detect handwritten documents and convert them into speech to help blind people read, and the accuracy rate of this system is 94-95\%. They used Pi cam and Raspberry pi as a module. Vaidya et al. (2020) pro-posed YOLVOv3 for a multi-name course of action to recognize any kind of article, and they achieved an accuracy of $85 \%$ in mobile phones and $89 \%$ in web applications. Only 80 distinct types of articles are compatible with the YOLOv3 dataset, which is Darknet-53 with 53 layers loading. Chiranjevulu et al. (2020) used ultrasonic sensors to detect obstacles without touching them using ultrasonic waves. The darkness and light can be detected by using the LDR sensor.

Adil et al. (2020) used Ultrasonic Sensor HC-SR04 and found 93 percent accuracy in distance detection. The author also used Voice Module ISD 1820. A critical component of the ISD1820 Voice Recorder Module is that it can store messages in its nonunstable memory and can be designed to store messages from 8 seconds to 20 seconds long.

2021- Present - Sumathy et al. (2021) The Arduino Uno microcontroller is utilized to handle the info information in the savvy direction framework. For any roll-off or ordinary movement of individuals under request, the MEMS (Micro Electro Mechanical System) accelerometer yields in every one of the three directions. This accelerometer is a device that detects movement, takes data on three axes, and combines it with the values of obstacle detection 
parameter values to make a conclusion based on the most optimal values. Mahesh et al. (2021) the photos were taken on a Raspberry Pi 4 Model B. The YOLO network is utilized to perceive and group objects. The perceived class is changed over to voice utilizing gTTS (Google Text to Speech module) and sent to the client's earphones, Choksi et al. (2021). The outwardly disabled individuals think that it is hard to move in with their environmental factors. Hindrance recognition and alarming can help them in their development. The proposed electronic white sticks comprises an impediment identification framework utilizing a profound learning model, ultrasonic sensor, and infrared sensor. It was tested on a group of visually impaired participants. Rahman et al. (2021) used Mask R-CNN after analyzing several methods like YOLO, SSD, and others RCNN for object detection and found a SUS score of $86 \%$. There are several sensors used, including Camera and micro-processor modules.

\section{Priorities Analysis}

Table 1 Here are the objectives of all the papers we have surveyed. When we surveyed our paper, we can see most of the papers are real-time object detection in outdoor or indoor. Some papers using voice commands to recognize objects in the surrounding. Some are using Android Smartphone's with a camera and network connection. In the Priority Analysis Table here, we covered all objective parts of our paper.

Table 1: Here are the objectives of all the papers we have surveyed.

\begin{tabular}{|c|c|}
\hline Ref. & Objectives \\
\hline (Adil et al., 2020) & Item discovery in the indoor and outside climate \\
\hline (Arora et al., 2019) & Continuous item discovery \\
\hline (Asati et al., 2019) & $\begin{array}{l}\text { The web camera, which catches the picture and subsequently groups it, is being used for } \\
\text { object acknowledgment and characterization. }\end{array}$ \\
\hline (Bashiri et al., 2018) & $\begin{array}{l}\text { A PC vision framework worked with a profound neural organization to help outwardly } \\
\text { debilitated people's versatility in clinical settings by appropriately identifying entryways, } \\
\text { steps, and signs, the most outstanding constructions. }\end{array}$ \\
\hline (Bastomi et al., 2019) & $\begin{array}{l}\text { Gauge distance of distinguished item through the camera which is joined with glasses, to ease } \\
\text { dazzle individuals who use it, recognize foreordained articles, to be specific people, tables, } \\
\text { seats, vehicles, bikes and motorbikes and the outcomes are changed over into sound structure } \\
\text { and associated with headphones for yield. }\end{array}$ \\
\hline (Bhandari et al., 2021) & Object detection in Outdoor \\
\hline (Bhole et al., 2020) & Item identification \\
\hline (Chen et al., 2019) & $\begin{array}{l}\text { A shrewd assistive framework for dazzle individuals would incorporate wearable savvy } \\
\text { glasses, an astute strolling stick, a cell phone application, and an online data stage. }\end{array}$ \\
\hline (Chiranjevulu et al., 2020) & Item identification in the outside climate \\
\hline (Choksi et al., 2021) & Item identification \\
\hline (Felix et al., 2018) & Assist using voice commands to recognize objects in the surrounding \\
\hline (Rahman et al., 2020) & Smart solution on blind people and home using Bangla voice command. \\
\hline (Gbenga et al., 2017) & $\begin{array}{l}\text { A minimal expense, lightweight framework utilizing a microcontroller that examinations flags } \\
\text { and informs outwardly disabled individuals of any snags, water, or dim spots by means of } \\
\text { blaring sounds. }\end{array}$ \\
\hline (Jain et al., 2018) & $\begin{array}{l}\text { A visual guide for outwardly impeded individuals in whom discourse orders are ack- } \\
\text { nowledged from the client tends to recognizable proof of articles and billboards. }\end{array}$ \\
\hline (Johari et al., 2020) & $\begin{array}{l}\text { The keen stick is highlighted with snag identification, traffic signal shading discovery, ringer- } \\
\text { based ready framework, area sharing. }\end{array}$ \\
\hline (Krishnan et al., 2016) & $\begin{array}{l}\text { The system works reliant upon the development of echolocation, pictures dealing with, and a } \\
\text { course structure. }\end{array}$ \\
\hline
\end{tabular}




\begin{tabular}{|c|l|}
\hline (Kumar et al., 2019) & $\begin{array}{l}\text { An article recognition approach for individuals who are outwardly impeded distinguishes } \\
\text { objects continuously on any gadget that executes this model. }\end{array}$ \\
\hline (Kunta et al., 2020) & $\begin{array}{l}\text { The Proposed brilliant stick is planned with a deterrent identification module, heat location, } \\
\text { water discovery, light recognition, pit, and flight of stairs identification. }\end{array}$ \\
\hline (Moharkar et al., 2020) & $\begin{array}{l}\text { A framework for outwardly tested individuals that utilize OCR and A.I. to identify text from } \\
\text { manually written archives. }\end{array}$ \\
\hline (Mule et al., 2020) & In-house object recognition \\
\hline (Nabiha et al., 2020) & Prototype for analyzing images and convert them into text \\
\hline (Parikh et al., 2018) & Android cell phone with a camera and organization association \\
\hline (Patel et al., 2018) & Object detection in the indoor environment \\
\hline (Pathak et al., 2020) & Real-time object detection \\
\hline (Rahman et al., 2021) & $\begin{array}{l}\text { A compositional plan of brilliant visually impaired colleague utilizing the instrument of } \\
\text { profound Learning installed with IoT with the application-based assistive framework by utili- } \\
\text { zing a shrewd visually impaired stick and Smart Cap with the camera module. }\end{array}$ \\
\hline (Subbiah et al., 2019) & $\begin{array}{l}\text { Discovery of hindrances, Identify the area, and furthermore, the objective way and Destination } \\
\text { way will be shipped off them in a type of the voice acknowledgment framework. }\end{array}$ \\
\hline (Sumathy et al., 2021) & $\begin{array}{l}\text { Identification of the hindrances and profundity and through voice yields the remote voice play- } \\
\text { back modem, to alarm them when they discovered an obstruction or impact. }\end{array}$ \\
\hline (Suraj et al., 2019) & $\begin{array}{l}\text { Identifying impediments that help the outwardly hindered as portability help with the nearest } \\
\text { obstruction utilizing the sonar rule and thus produces vibrotactile input that advises the client } \\
\text { about the course of the item. }\end{array}$ \\
\hline (Vaidya et al., 2020) & $\begin{array}{l}\text { They are informing the visually impaired individuals about the items in their way through the } \\
\text { sound yield. }\end{array}$ \\
\hline (Yohannes et al., 2020) & Object detection \\
\hline
\end{tabular}

\section{Methodologies' employed in assistive technology}

\section{Solution Based on Sensors}

Sensors are the essential gadgets that are frequently used to gather ecological information, and most Travel Aids normally include sensors. A few sensors that have been utilized in the past and are presently being employed by researchers in this field are included. Ultrasonic sensors are the most often used sensors because they are affordable and are un-affected by object color or transparency. A transducer is utilized in an ultrasonic sensor to communicate and get ultrasonic heartbeats that send information about the closeness of an article. This sensor uses an ultrasonic wave that reflects upon colliding with any objects in front. It estimates the time between transmission and receiving to estimate the distance to the object. However, it is incapable of detecting obstructions at ground level. Because of its large field of view but limited range, the Wide-angle Camera is used for surveillance. Monocular Vision Camera offers high-goal far-off detecting pictures for a minimal price. It is, notwithstanding, contrary to the

UniversePG I www.universepg.com natural eye visual framework. The Binocular Vision Sensor records pictures at a foreordained recurrence, taking into account 3D vision. It is very exorbitant and has a particular core interest. An infrared sensor is a kind of electrical gear that produces light to identify certain components of its current circumstance. It is a radiation-sensitive optoelectronic module having infrared wavelength sensitivity ranging between $780 \mathrm{~nm}$ and $50 \mu \mathrm{m}$. An I.R. sensor can distinguish movement just as to quantify the warmth of a thing. These sensors simply screen infrared radiation instead of transmitting it, which is named a detached I.R. sensor. Commonly, everything in the infrared reach produces a type of warm radiation. Such radiation is imperceptible to human sight, yet an infrared sensor can recognize them. The producer is only an infrared LED (Light Emitting Diode), and the locator is basically an infrared photodiode receptive to infrared light of a similar frequency as the IR LED. Most of our surveyed paper used different Ultrasonic sensors and I.R. sensors. Here at (Chiranjevulu et al., 2020; Rahman et al., 2020; Rahman et al., 2021), they have used LDR sensors to detect light. At the 
point when light beams on the LDR, the obstruction brings down and increments in obscurity. When an LDR is set to indefinite quality, it has a high resistance, but when it is cared for in the light, it has a lower resistance. At (Rahman et al., 2021), a gas pedal sensor that identifies movement levels is remembered for the recommended design. In case the outwardly debilitated individual falls, the gas pedal sensor will distinguish the incident and pass on the pertinent data to the microcontroller. The microcontroller will then establish a connection with the permitted supervisor over a cloud specialist. Then, at (Johari et al., 2020), they used a Color Sensor. The TCS3200 chip is intended to detect the color of light that reaches it. It also has a photodiode array. These photodiodes are protected by four different types of filters. Sixteen sensors are fitted with a RED filter, allowing them to measure just the component of red in the incident light. And there are water sensors used at (Rahman et al., 2021) and (Gbenga et al., 2017) for detecting water for blind people. The sensor-based system can be a good solution for blind people is because it can detect obstacles and also can detect some other elements too. But there still are some detecting problems. Like those systems can't detect the exact structure of that object and can say what it is. A sensor-based system can be a good solution for blind people but not the best one.

Table 2: Here are the sensor names of all the papers we have surveyed.

\begin{tabular}{|c|c|}
\hline Ref. & Sensor Name \\
\hline $\begin{array}{l}\text { (Adil et al., 2020), (Asatiet al., 2019), (Chiranjevulu et al., 2020), (Gbenga et al., 2017), (Jain } \text { et } \\
\text { al., 2018), (Johari et al., 2020), (Krishnan et al., 2016), (Mahesh et al., 2021), (Patel et al., } \\
\text { 2018), (Rahman } \text { et al., 2021), (Subbiah et al., 2019), (Sumathy et al., 2021), (Suraj et al., 2019), } \\
\text { (Yohannes } \text { et al., 2020) }\end{array}$ & Ultrasonic Sensor \\
\hline (Nabiha et al., 2020) & Ultrasonic Transducers \\
\hline $\begin{array}{l}\text { (Chen et al., 2019), (Kunta et al., 2020), (Patel et al., 2018), (Rahman et al., 2021), (Subbiah et } \\
\text { al., 2019), (Sumathy et al., 2021), (Yohannes et al., 2020) }\end{array}$ & IR Sensor \\
\hline (Chiranjevulu et al., 2020), (Rahman et al., 2021), (Yohannes et al., 2020), (Rahman et al., 2020) & LDR Sensor \\
\hline (Rahman et al., 2021), (Yohannes et al., 2020) & Accelerator Sensor \\
\hline (Johari et al., 2020) & $\begin{array}{c}\text { TCS3200color } \\
\text { sensor }\end{array}$ \\
\hline (Gbenga et al., 2017), (Rahman et al., 2021) & Water Sensor \\
\hline
\end{tabular}

\section{Solution Based on Image Processing and A.I.}

Picture preparing is additionally one more procedure utilized by numerous innovations to identify pictures caught by cameras. Picture handling is an approach to lead procedure on a picture to separate significant information from it. It is a type of sign preparing in which the information is a picture and the yield maybe a picture or picture attributes. For this reason, it utilizes an assortment of approaches, including picture division, profundity map assessment, and synchronous limitation or planning. Picture division is the way toward partitioning a picture into unmistakable segments known as super pixels. The goal of the division is to redo the image with the objective that it ends up being more enormous and less difficult to review as time goes on. The term "image segmentation" refers to the process of separating the region of an image that contains objects and edges.

UniversePG I www.universepg.com
An importance map is a picture or set of pictures containing information showing the distance between the surfaces of scene objects as per a perspective. Depth Map Estimation refers to a collection of approaches and algorithms for determining the portrayal of spatial structure in a scene. The Simultaneous Localization and Mapping (SLAM) method assists in the construction or updating of a new environment's map while also keeping track of an agent's position. A few Machines Learning and Deep Learning draws near, like SVM, CNN, and LSTM, have likewise been used to help the outwardly disabled lately. A.I. Is an information investigation system that robotizes the development of logical models is a subfield of manmade brainpower that is likewise established on the idea that frameworks can gain from information, recognize examples, and settle on decisions with practically zero human connection. A.I. Techniques 
empower P.C.s to learn without the requirement for unequivocal programming. It is the assessment of assessments and certain models to do a given errand. Huge Learning is a piece of A.I. assessments that pulls highlights from input information. The majority of these models rely upon Artificial Neural Networks (ANNs), like Convolutional Neural Networks (CNN, or ConvNet). Learning can occur in a regulated, solo, or half and half climate. The term SVM alludes to a regulated model that dissects information for relapse and grouping investigation. Here we have seen that Deep CNN predictive models have the most accuracy rate, 98\% (Bashiri et al., 2018). On The other hand,
Faster RCNN, SSD has the lowest rate of accuracy, $75 \%$ (Kumar et al., 2019). And other models like Model B, YOLO network, ResNet50, SSD, OpenCV, Mask R-CNN, etc. and have an accuracy of $85 \%$ to 97.80\%. At (Parikh et al., 2018), they have used three models, which areInceptionV3, Res-Net50, and VGG19, and they found accuracy rates of $96.4 \%$, 94.78\%, 90.88\% accordingly. And at (Arora et al., 2019), they used Single Shot Detection (SSD), Mobile Net and found accuracy rates of $97.80 \%$, 97.04\%. At (Mule et al., 2020), they used a hybrid algorithm containing SSD lite, Mobile Net V2, OpenCV and found $85 \%$ accuracy.

Table 3: Here are the models and accuracy of all the papers we have surveyed.

\begin{tabular}{|c|c|c|}
\hline Ref. & Model & Accuracy \\
\hline (Adil et al., 2020) & Sensor-Based & $93 \%$ \\
\hline (Arora et al., 2019) & Single Shot Detection (SSD), MobileNet. & $97.80 \%, 97.04 \%$ \\
\hline (Asati et al., 2019) & YOLO and CNN & - \\
\hline (Bashiri et al., 2018) & Deep CNN predictive models & $98 \%$ \\
\hline (Bastomi et al., 2019) & $\mathrm{CNN}$ & $93.33 \%$ \\
\hline (Bhandari et al., 2021) & Sensor-Based & - \\
\hline (Bhole et al., 2020) & Single-Shot Detection (SSD), Inception v3 & $67.8,92.5,90.2$ \\
\hline (Chen et al., 2019) & Infrared (IR) transceiver sensor-based detection & - \\
\hline (Chiranjevulu et al., 2020) & Sensor-Based & - \\
\hline (Choksi et al., 2021) & CNN Model & - \\
\hline (Felix et al., 2018) & Sensor-Based & \begin{tabular}{|c|}
$80 \%$ to $90 \%$ \\
\end{tabular} \\
\hline (Rahman et al., 2020) & Sensor-Based, App-Based & SUS ( $28 \%$ strongly endorse, $56 \%$ endorse) \\
\hline (Gbenga et al., 2017) & Obstacle Detection by Ultrasonic sensor & - \\
\hline (Jain et al., 2018) & Haar feature-based cascade classifiers & - \\
\hline (Johari et al., 2020) & Traffic Light Crossing (TLC) Algorithm & - \\
\hline (Krishnan et al., 2016) & Sensor-Based, SURF & - \\
\hline (Kumar et al., 2019) & Faster RCNN, SSD & $75 \%$ \\
\hline (Kunta et al., 2020) & Sensor-Based & - \\
\hline (Moharkar et al., 2020) & CNN & $94-95 \%$ \\
\hline (Mule et al., 2020) & SSDlite, MobileNet V2, OpenCV & $85 \%$ \\
\hline (Nabiha et al., 2020) & Sensor-Based & - \\
\hline (Parikh et al., 2018) & InceptionV3, ResNet50 and VGG19 & $96.4 \%, 94.78 \%, 90.88 \%$ \\
\hline (Patel et al., 2018) & Sensor-Based & - \\
\hline (Pathak et al., 2020) & Model B, YOLO network & $97 \%$ \\
\hline (Rahman et al., 2021) & Mask R-CNN & $86 \%$ \\
\hline (Subbiah et al., 2019) & Sensor-Based & - \\
\hline (Sumathy et al., 2021) & Sensor-Based & - \\
\hline
\end{tabular}

\begin{tabular}{|c|c|c|}
\hline (Suraj et al., 2019) & Sensor-Based & $\begin{array}{c}\text { Weight (40.00\%), Dimension (33.3\%), } \\
\text { Mobility Confidence (26.6\%), Mobility } \\
\text { Assistance (60.0\%) }\end{array}$ \\
\hline (Vaidya et al., 2020) & YOLOv3-tiny & $85.5 \%$ (mobile phones), 89\% (Web application) \\
\hline (Yohannes et al., 2020) & Sensor-Based & - \\
\hline
\end{tabular}


Here most of the papers we have surveyed are sensorbased. So, they don't have any particular accuracy rate there. There are different object detection methods used in the others, which are using cameras and camera modules. We can see a comparative Table 3 of the accuracy and models of our surveyed paper.

\section{App-based Solution}

There are a couple of invigorating application-based applications expected for the vision crippled that probably go as an extra course of action of eyes for them. People living with a visual lack or a visual handicap have discovered that applications have simplified their lives.

\section{LookTel via IPPLEX}

(LookTel, 2021) LookTel is building a series of innovative assistive Smartphone applications that will bring today's most powerful detection technology to the assistance of those who are blind or have limited vision. Users may scan and quickly detect things such as packaged products, drink cans, currency, DVDs, and locations such as signs and stores using this realtime recognition technology. LookTel has two open programs for the open iPhone, iPod Contact, iPad, and Mac PCs, LookTel Money Reader and LookTel Recognizer, with more in the works. Working in close cooperation with the outwardly debilitated populace, paying attention to and understanding their one-of-akind necessities, LookTel makes historic arrangements that enable their everyday lives.

LookTel Money Reader can see different kinds of money and clear it, class, allowing the obviously weakened to affirm their money. Clients simply aim their iOS device at the bill, take a picture with the camera, and trust that the total will be broad-cast for all to hear. Prior to this program, the unmistakably upset had to rely on others to reveal the size of each charge; however, customers can now count their cash independently.

\section{KNFB Reader by the National Federation of the Blind and Sensotec NV}

(KNFB Reader, 2021) KNFB Reader is an honor winning cell phone application that changes message to voice or message to Braille for visually impaired, low-vision, dyslexic, and other print incapacitated clients. Receipts, bundle marks, and mail, item and UniversePG I www.universepg.com dietary data, print on the screen of your P.C. or Table, longer papers like books and client manuals, Private archives, for example, charge records, contract archives, solicitations, and clinical reports, EBooks and reports in the ePub design, just as materials in more than thirty dialects may be perused by KNFB Reader.

\section{SayText by DocScanner}

(Say Text Apps for blind and visually impaired people, 2021) SayText speaks the words in the picture aloud. It is designed for visually challenged people. SayText is a free product developed by the DocScanner team. SayText examines the message contained inside an image, such as a medical building or a café menu, and interprets it so that anybody may hear it. At that moment, the application's Optical Character Recognition tool analyses the material. Tap the screen to check whether there are any declarations. Once you've figured it out, swipe right to hear the account read out loud so that everyone can hear it.

TapTapSee by CloudSight Inc - (TapTapSee, 2021) TapTapSee is smartphone camera software designed for visually impaired and blind people that use the Cloud Sight Image Recognition API. TapTapSee takes a photo or video of anything and detects it for the user using the device's camera and Voiceover. Clients must double tap the right half of the screen or the left half of the screen to take images. TapTapSee examines and recognizes any a few dimensional thing at any point right away. The character is then recited for all to hear by means of the gadget's Voiceover.

Be My Eyes - (Be My Eyes, 2021) Be My Eyes is an application that associations outwardly disabled and low vision individuals with found volunteers and corporate specialists through live video gatherings for visual assistance. Regular schedule, located volunteers offer their eyes to finish exercises huge and minimal to help visually impaired, and low vision people is turning out to be more independent. As a person who is blind or has limited vision, their volunteers are pleased to assist people who require visual aid. Users and a volunteer may connect directly and fix a problem via a live video conversation. The volunteer will assist in determining which way to point the user's camera, what to focus on, and when to switch on the torch. 
Table 4: Here are the application name, platform, key features, and matching features of all the papers we have surveyed.

\begin{tabular}{|c|c|c|c|}
\hline $\begin{array}{c}\text { Application } \\
\text { Name }\end{array}$ & Platform & Key Feature & Matching Feature \\
\hline Helping App & Android & With voice commands, it can control all Android capabilities. & Yes \\
\hline Looktel & IOS & $\begin{array}{l}\text { Right away, perceives money and talks the section, empowering } \\
\text { individuals encountering visual weaknesses or visual Impairment } \\
\text { to rapidly and effectively distinguish and tally bills. }\end{array}$ & Yes \\
\hline $\begin{array}{c}\text { KNFB } \\
\text { Reader }\end{array}$ & $\begin{array}{c}\text { Android } \\
\text { IOS, } \\
\text { Windows }\end{array}$ & $\begin{array}{c}\text { KNFB Reader is a cell phone application that changes the text to } \\
\text { voice or text to Braille for visually impaired, low-vision, dyslexic, } \\
\text { and other print-incapacitated clients. }\end{array}$ & Yes \\
\hline TapTapSee & $\begin{array}{c}\text { Android } \\
\text { IOS }\end{array}$ & $\begin{array}{r}\text { TapTapSee uses your cell camera and Voice Over to snap an image } \\
\text { or video of anything and recollect it rapidly. }\end{array}$ & Yes \\
\hline Eyes & Android & $\begin{array}{l}\text { It's an app that connects people who are purportedly disabled with } \\
\text { volunteers who provide virtual assistance via a live video call. Be } \\
\text { My Eyes comes in } 180 \text { different languages. }\end{array}$ & No \\
\hline
\end{tabular}

Table 4 records the entirety of the gadgets and classifiers them into five classifications: gadget name, examination type, inclusion, object type, and conveying mode. The "Analysis Type" category is further split up into two subcategories: online and offline mode. The "Coverage" category is further divided into three sub-categories: indoor, outdoor, and both. The term "Object Type" is further split into three subcategories: static, dynamic, and both. "Carrying Mode" is further split into two categories: Wearable and Hand-held. The "Online" category indicates devices that require an internet connection to function, whereas the "Offline" category indicates gadgets that do not require an internet connection to function. The term "indoor" refers to equipment that can only execute its functions inside.

The "Outside" category de-notes that the item is only suited for use in an outdoor environment. The category "Both" implies that the gadgets may function both indoors and outside. The "Static" category indicates that the device can only identify static objects, whereas the "Dynamic" category indicates that the device can only detect moving things. Again, the category "Both" indicates that the gadget can identify both static and dynamic items. The "Wearable" category includes gadgets that may be worn, whereas the "Handheld" category includes nonwearable equipment that must be handled in the hands.

UniversePG I www.universepg.com

\section{Architecture}

Different authors used different equipment and technology to build their proposed system for the blind, like Raspberry Pi, Arduino, etc. The Raspberry Pi is an expense proficient, little chip that utilizes a P.C. screen or T.V. and works with a customary console and mouse. It is a minuscule contraption that permits people, everything being equal, to explore different avenues regarding registering and figure out how to write in dialects like Scratch and Python. It does all that a P.C. does, from perusing the web and observing top quality recordings to making work-sheets, word handling, and playing P.C. games. In addition, the Raspberry Pi can talk with the remainder of the world and has been utilized in a wide extent of cutting-edge maker projects, including music machines and parent pointers, similar to environment stations and tweeting aviaries with infrared cameras (Raspberry Pi, 2021). And also, those devices like smart blind sticks and other assistive technology. Arduino is an open-source electrical structure made on essential hardware and programming. Arduino sheets can examine inputs like a light on a sensor, a fingertip on a key, or a Twitter tweet and change them into yields like inducing motors, turning on an especially LED, or posting anything on the web. You might guide your board to perform anything by passing a progression of guidelines to the board's microcontroller. To do this appropriately, clients can use the Arduino programming language (thinking about Wiring) and the Arduino Software (IDE), which depends after Processing. All 
through the long haul, Arduino has filled in as the frontal cortex of thousands of adventures, going from fundamental family things to legitimate present day equipment. An overall neighborhood creator understudies, novices, skilled workers, designers, and trained professionals-has adjusted to this open-source stage, and their undertakings have pushed toward a monster measure of open information that may be of gigantic benefit to the two novices and specialists (Arduino, 2021).

Table 5: Here are the models and equipment of all the papers we have surveyed.

\begin{tabular}{|c|c|c|}
\hline Ref. & Model & Equipment \\
\hline (Adil et al., 2020) & Sensor-Based & Arduino UNO, Ultrasonic Sensor HC-SR04, Voice Module ISD 1820 \\
\hline (Arora et al., 2019) & $\begin{array}{l}\text { Single Shot Detection } \\
\text { (SSD), MobileNet. }\end{array}$ & Raspberry pi, Smartphones \\
\hline (Asatiet al., 2019) & YOLO and CNN & HR-SO4 ultrasonic sensors, Pi camera \\
\hline (Bashiri et al., 2018) & $\begin{array}{l}\text { Deep CNN predictive } \\
\text { models }\end{array}$ & - \\
\hline (Bastomi et al., 2019) & $\mathrm{CNN}$ & Mini P.C., Camera, and Battery \\
\hline (Bhandari et al., 2021) & Sensor-Based & Primarily $\mathrm{CNN}$ architectures \\
\hline (Bhole et al., 2020) & $\begin{array}{l}\text { Single-Shot Detection } \\
\text { (SSD), Inception v3 }\end{array}$ & Ultrasonic sensors, I.R. sensors \\
\hline (Chen et al., 2019) & $\begin{array}{l}\text { Infrared (I.R.) } \\
\text { transceiver sensor- } \\
\text { based detection }\end{array}$ & $\begin{array}{l}\text { Infrared (I.R.) handset sensor module, 6-hub miniature electro- } \\
\text { mechanical (MEM) sensor module, microcontroller unit (MCU), } \\
\text { Bluetooth low energy (BLE) remote correspondence module, bat- } \\
\text { tery charging module, vibration engine, a GPS module, an MPU, a } \\
\text { LoRa-based LPWAN remote correspondence module. }\end{array}$ \\
\hline (Chiranjevulu et al., 2020) & Sensor-Based & Ultrasonic sensors, LDR sensors. \\
\hline (Choksi et al., 2021) & CNN Model & Ultrasonic sensor, infrared sensor \\
\hline (Felix et al., 2018) & Sensor-Based & Cloud Vision API, REST API \\
\hline (Rahman et al., 2020) & Sensor-Based & $\begin{array}{l}\text { LPG, GPS, Motion Sensor, Ultrasonic, Automation device, Buzzer, } \\
\text { Bluetooth. }\end{array}$ \\
\hline (Gbenga et al., 2017) & $\begin{array}{l}\text { Obstacle Detection by } \\
\text { Ultrasonic sensor }\end{array}$ & $\begin{array}{l}\text { Ultrasonic sensor, Arduino UNO is a microcontroller board depen- } \\
\text { dent on the ATmega328p, Water sensor, LCD, R.F. Receiver, } \\
\text { Switch, Buzzer, Voltage Regulator, Power supply }\end{array}$ \\
\hline (Jain et al., 2018) & $\begin{array}{l}\text { Haar feature-based } \\
\text { cascade classifiers }\end{array}$ & Raspberry Pi, Pi camera, Ultrasonic Sensor, Open CV, and Python. \\
\hline (Johari et al., 2020) & $\begin{array}{l}\text { Traffic Light Crossing } \\
\text { (TLC) Algorithm }\end{array}$ & Arduino Uno, TCS3200 color sensor, Ultrasonic sensor \\
\hline (Krishnan et al., 2016) & Sensor-Based, SURF & $\begin{array}{l}\text { Diameter Two- } 60 \mathrm{~mm} \text { diameter wheels, 360-degree continuous } \\
\text { rotation servo motors, Camera (Pixy CMUCam5), ultrasonic sen- } \\
\text { sor, Bluetooth module, smartphone }\end{array}$ \\
\hline (Kumar et al., 2019) & Faster RCNN, SSD & - \\
\hline (Kunta et al., 2020) & Sensor-Based & Infrared (IR) sensor, Raspberry Pi, \\
\hline (Moharkar et al., 2020) & $\mathrm{CNN}$ & Pi camera module \\
\hline (Mule et al., 2020) & $\begin{array}{l}\text { SSDlite, MobileNet } \\
\text { V2, OpenCV }\end{array}$ & Raspberry pi \\
\hline (Nabiha et al., 2020) & Sensor-Based & $\begin{array}{l}\text { Raspberry pi 3, model B+, Raspberry Pi Camera v2, Ultrasonic } \\
\text { transducers }\end{array}$ \\
\hline (Parikh et al., 2018) & $\begin{array}{l}\text { InceptionV3, } \\
\text { ResNet50 and VGG19 }\end{array}$ & Android Smartphone with a camera \\
\hline (Patel et al., 2018) & Sensor-Based & USB webcam, Ultrasonic Sensor, and Infrared Sensor \\
\hline
\end{tabular}




\begin{tabular}{|l|l|l|}
\hline (Pathak et al., 2020) & $\begin{array}{l}\text { Model B, YOLO } \\
\text { network }\end{array}$ & Raspberry Pi 4, gTTS (Google Text to Speech module) \\
\hline (Rahman et al., 2021) & Mask R-CNN & $\begin{array}{l}\text { Raspberry pi, Camera module, Headphone, Ultrasonic Sensor, Ac- } \\
\text { celerator Sensor, Water sensor, LDR Sensor, I.R. Sensor, Vibrator, } \\
\text { Buzzer }\end{array}$ \\
\hline (Subbiah et al., 2019) & Sensor-Based & Raspberry Pi, Ultrasonic Sensor, I.R. Sensor, GPS, and GSM \\
\hline (Sumathy et al., 2021) & Sensor-Based & Arduino Uno microcontroller, I.R. and Ultrasonic Sensor \\
\hline (Suraj et al., 2019) & Sensor-Based & $\begin{array}{l}\text { Microcontroller, three ultrasonic sensors, two vibration engines, a } \\
\text { ringer, power source, a GPS module, and a GSM Module. }\end{array}$ \\
\hline (Vaidya et al., 2020) & YOLOv3-tiny & OpenCV, TensorFlow, Darknet, Smartphone. \\
\hline (Yohannes et al., 2020) & Sensor-Based & $\begin{array}{l}\text { Ultrasonic sensor, I.R. sensor, accelerator sensor, and LDR sensor } \\
\text { (Appendix I) }\end{array}$ \\
\hline
\end{tabular}

Table 6: Here are the limitations, and future works of all the papers we have surveyed.

\begin{tabular}{|c|c|c|}
\hline Ref. & Limitations & Future Works \\
\hline $\begin{array}{l}\text { (Adil et al., } \\
\text { 2020) }\end{array}$ & - & - \\
\hline $\begin{array}{l}\text { (Arora et al., } \\
\text { 2019) }\end{array}$ & $\begin{array}{l}\text { This work can additionally be progressed for face } \\
\text { affirmation to learn regular appearances experienced } \\
\text { by the outwardly hindered person. }\end{array}$ & $\begin{array}{l}\text { We can utilize high-velocity complex calcul- } \\
\text { ations for expanding precision. }\end{array}$ \\
\hline $\begin{array}{l}\text { (Asati et al., } \\
\text { 2019) }\end{array}$ & - & - \\
\hline $\begin{array}{c}\text { (Bashiri et al., } \\
\text { 2018) }\end{array}$ & $\begin{array}{l}\text { The present work identified hospital signs; however, } \\
\text { signs seem to be considerably more than just detec- } \\
\text { ting and recognizing. }\end{array}$ & $\begin{array}{l}\text { Will make an interpretation of a clinic sign into } \\
\text { a more significant expression. We will widen } \\
\text { our rundown of objects to incorporate lifts, snags, } \\
\text { and lifts to resolve the issue of constant multi- } \\
\text { object location or distinguishing numerous } \\
\text { things in a solitary picture. Picture text-to-sound } \\
\text { interpretation and the improvement of corres- } \\
\text { pondence and customer level advances will like- } \\
\text { wise be incorporated. }\end{array}$ \\
\hline $\begin{array}{l}\text { (Bastomi et } \\
\text { al., 2019) }\end{array}$ & $\begin{array}{l}\text { CNN framework execution when Recognizing ob- } \\
\text { jects in the kind of vehicles, tables, seats, bicycles, } \\
\text { individuals, and motorbikes have their specific } \\
\text { ascribes from various headings, and Stereo Vision } \\
\text { estimation is just in the scope of } 50 \mathrm{~cm} \text { to about } \\
300 \mathrm{~cm} \text {. }\end{array}$ & - \\
\hline $\begin{array}{l}\text { (Bhandari et } \\
\text { al., 2021) }\end{array}$ & $\begin{array}{l}\text { The system can't assist with opening and closing } \\
\text { doors. }\end{array}$ & ( \\
\hline $\begin{array}{l}\text { (Bhole et al., } \\
\text { 2020) }\end{array}$ & - & $\begin{array}{l}\text { Future work can be done to make a face and } \\
\text { cash acknowledgment parody verification. }\end{array}$ \\
\hline $\begin{array}{l}\text { (Chen et al., } \\
\text { 2019) }\end{array}$ & - & $\begin{array}{l}\text { Profound learning strategies will be coordinated } \\
\text { for recognizing front pictures, for example, traf- } \\
\text { fic signs, and shrewd strolling directing func- } \\
\text { tionalities will be created. }\end{array}$ \\
\hline $\begin{array}{l}\text { (Chiranjevulu } \\
\text { et al., 2020) }\end{array}$ & - & - \\
\hline $\begin{array}{c}\text { (Choksi et al., } \\
\text { 2021) }\end{array}$ & - & - \\
\hline (Felix et al., & - & Executed in a multilingual application so a \\
\hline
\end{tabular}




\begin{tabular}{|c|c|c|}
\hline 2018) & & $\begin{array}{l}\text { client can use it in their local language without } \\
\text { trouble The Internet of Things (IoT) can be uti- } \\
\text { lized to carry out a framework. The framework } \\
\text { will actually want to all the more likely decipher } \\
\text { the text-based depiction. }\end{array}$ \\
\hline $\begin{array}{l}\text { (Rahman et } \\
\text { al., 2020) }\end{array}$ & - & $\begin{array}{l}\text { Home automation module will be developed } \\
\text { through server for real-time test; app will be } \\
\text { available for all users not for authorized user. }\end{array}$ \\
\hline $\begin{array}{c}\text { (Gbenga et al., } \\
\text { 2017) }\end{array}$ & $\begin{array}{l}\text { This technology, as well as the nature of the im- } \\
\text { pediment, cannot identify holes. }\end{array}$ & $\begin{array}{l}\text { A worldwide situating approach that utilizes } \\
\text { GPS to decide the client's area and GSM mod- } \\
\text { ules to impart the area to a family member or } \\
\text { parental figure. It ought to likewise have the } \\
\text { option to oblige a wide scope of grasps for adap- } \\
\text { table dealing with. }\end{array}$ \\
\hline $\begin{array}{l}\text { (Jain et al., } \\
\text { 2018) }\end{array}$ & - & - \\
\hline $\begin{array}{l}\text { (Johari et al., } \\
\text { 2020) }\end{array}$ & - & $\begin{array}{l}\text { Later on, the stick is expected to have voice } \\
\text { confirmation and a GPS coordinating system. }\end{array}$ \\
\hline $\begin{array}{l}\text { (Krishnan et } \\
\text { al., 2016) }\end{array}$ & - & $\begin{array}{l}\text { Improvement of the item acknowledgment } \\
\text { framework so it can recognize and distinguish } \\
\text { protests better in testing natural conditions and } \\
\text { better calculations could be formed for the gad- } \\
\text { get to explore utilizing dynamic picture ack- } \\
\text { nowledgment. }\end{array}$ \\
\hline $\begin{array}{c}\text { (Kumar et al., } \\
\text { 2019) }\end{array}$ & - & - \\
\hline $\begin{array}{c}\text { (Kunta et al., } \\
\text { 2020) }\end{array}$ & - & $\begin{array}{l}\text { Dynamic capacities by utilizing different sorts } \\
\text { of sensors. }\end{array}$ \\
\hline $\begin{array}{l}\text { (Moharkar et } \\
\text { al., 2020) }\end{array}$ & - & $\begin{array}{l}\text { To improve the findings, the dataset can be } \\
\text { modified. We would also experiment with chan- } \\
\text { ging the layers of the CNN to see if we could } \\
\text { get a better outcome. This can be carried out } \\
\text { with a Raspberry } \mathrm{Pi} \text { and transformed into an } \\
\text { undeniable application to help the outwardly } \\
\text { crippled. }\end{array}$ \\
\hline $\begin{array}{l}\text { (Mule et al., } \\
\text { 2020) }\end{array}$ & - & - \\
\hline $\begin{array}{c}\text { (Nabiha et al., } \\
\text { 2020) }\end{array}$ & $\begin{array}{l}\text { Outwardly debilitated individuals just pay attention } \\
\text { to a screen peruse perusing the text shown on the } \\
\text { screen. They don't typically get the opportunity to } \\
\text { know the right spelling of a specific word, parti- } \\
\text { cularly when it's clinical terms and so forth. }\end{array}$ & $\begin{array}{l}\text { Utilizing the GPRS innovation, this framework } \\
\text { would be refreshed to an electronic checking } \\
\text { framework, permitting clients to get to the } \\
\text { framework distantly through the Internet. In } \\
\text { addition, an improvement would be made to } \\
\text { allow for the surveillance of a greater area. Fur- } \\
\text { thermore, sensors like a barometric pressing } \\
\text { factor sensor, a gas indicator for air quality } \\
\text { observing, and a web interface would be fused } \\
\text { into a solitary framework that couldn't just } \\
\text { gauge yet additionally assess temperature and } \\
\text { moistness factors. }\end{array}$ \\
\hline $\begin{array}{l}\text { (Parikh et al., } \\
\text { 2018) }\end{array}$ & - & $\begin{array}{l}\text { Outdoor obstacle photos from a wider range of } \\
\text { sources can be utilized. }\end{array}$ \\
\hline
\end{tabular}




\begin{tabular}{|c|c|c|}
\hline $\begin{array}{l}\text { (Patel et al., } \\
\text { 2018) }\end{array}$ & It is not tested in outdoor environments. & - \\
\hline $\begin{array}{l}\text { (Pathak et al., } \\
\text { 2020) }\end{array}$ & - & $\begin{array}{l}\text { By joining cards with GPU in the equipment } \\
\text { and cloud-based organization execution, the to } \\
\text { some degree daze individual will actually want } \\
\text { to accomplish total autonomy both inside and } \\
\text { outside. }\end{array}$ \\
\hline $\begin{array}{l}\text { (Rahman et } \\
\text { al., 2021) }\end{array}$ & $\begin{array}{l}\text { There are only a few sensors and devices in the } \\
\text { model. Another requirement is that, in view of the } \\
\text { assortment of things, the model uses a connected } \\
\text { model in object recognizable proof with a fore- } \\
\text { ordained number of genuine pictures. }\end{array}$ & $\begin{array}{l}\text { A couple of kinds of sensors, for instance, the } \\
\text { M.Q. gas sensor and the fire sensor, will be } \\
\text { merged, and the arrangement will be ready in } \\
\text { the object area using a tremendous picture data- } \\
\text { set to ensure an optimal result. }\end{array}$ \\
\hline $\begin{array}{c}\text { (Subbiah et al., } \\
\text { 2019) }\end{array}$ & - & $\begin{array}{l}\text { Applying different types of sensors to increase } \\
\text { decision-making capabilities }\end{array}$ \\
\hline $\begin{array}{l}\text { (Sumathy et } \\
\text { al., 2021) }\end{array}$ & $\begin{array}{l}\text { The MEMS (Micro Electro Mechanical System) } \\
\text { accelerometer will respond to even minor shocks, } \\
\text { making the difference output or error difficult to } \\
\text { estimate. }\end{array}$ & $\begin{array}{l}\text { As an expansion of this work, in case of a mis- } \\
\text { hap or crisis, similar data might be shipped off } \\
\text { the closest emergency clinic/wellbeing office, } \\
\text { permitting them to act rapidly to save the exis- } \\
\text { tence of the people in question. In addition to } \\
\text { the latitude and longitude information, future } \\
\text { works will include the correct address. }\end{array}$ \\
\hline $\begin{array}{c}\text { (Suraj et al., } \\
\text { 2019) }\end{array}$ & $\begin{array}{l}\text { Recognizing just the closest deterrents yet at the } \\
\text { same time can't tackle the outwardly disabled in- } \\
\text { dividual's concern in seeing the climate. }\end{array}$ & $\begin{array}{l}\text { The proposed framework comprised of a small } \\
\text { example size, and the test climate was restricted } \\
\text { to a school ground or a few restricted desti- } \\
\text { nations that they knew about. In the future; we } \\
\text { ought to incorporate more examples with that } \\
\text { framework. }\end{array}$ \\
\hline $\begin{array}{c}\text { (Vaidya et al., } \\
\text { 2020) }\end{array}$ & $\begin{array}{l}\text { Things should not be placed too close to the camera } \\
\text { chart and should be placed further away than the } \\
\text { length of the assembly mark. For situations where } \\
\text { the thing is exceptionally far and too small to even } \\
\text { consider evening con-template evening considers } \\
\text { being gotten, this judgment has a low Mean Average } \\
\text { Precision. Because the authority module of the re- } \\
\text { mote isn't used, the presence of sound has no effect } \\
\text { on the region. }\end{array}$ & $\begin{array}{l}\text { The accuracy of identification in murkiness } \\
\text { should also be increased when distinguishing } \\
\text { things that are stowed away by impediments in } \\
\text { front of them; the distance of the article from } \\
\text { the camera is also a factor that can be combined. }\end{array}$ \\
\hline $\begin{array}{l}\text { (Yohannes et } \\
\text { al., 2020) }\end{array}$ & - & - \\
\hline
\end{tabular}

Table 7: Here are the network types, models, and advantages of all the papers we have surveyed.

\begin{tabular}{|c|c|l|}
\hline Network Type & Model & Advantage \\
\hline CNN & D-CNN & Great Accuracy \\
\hline CNN & YOLOv2 & Increases object detecting accuracy and speed \\
\hline CNN & SSD & Achieves a better combination of speed and accuracy \\
\hline CNN & MASK R-CNN & $\begin{array}{l}\text { Targeted at solving the challenge of instance segmentation in machine learning or } \\
\text { computer vision }\end{array}$ \\
\hline CNN & Faster R-CNN & has stronger map \\
\hline CNN & Inception v3 & $\begin{array}{l}\text { It is a famous picture preparing model that has been shown to accomplish better } \\
\text { compared to 78.1 percent precision on the ImageNet dataset (Advanced Guide to } \\
\text { Inception v3 on Cloud TPU, 2021). }\end{array}$ \\
\hline
\end{tabular}




\section{RESULTS AND DISCUSSION:}

As indicated by the writing audit, sensor-based frameworks were made to help outwardly debilitated individuals in route and impediment location (Preceding, 2000). Ultrasonic sensors and radar sensors were joined into the stick or other wear able/handheld contraptions to make them more pleasing to use. Then, until 2015, camera composed contraptions were made using diverse picture taking care of methodologies, which achieved devices that were to some degree heavier than prior ones as a result of the weight of cameras.

Table 8: Multi-boundary investigation of different devices utilized by visually impaired persons.

\begin{tabular}{|c|c|c|c|c|c|}
\hline Device & Year & $\begin{array}{l}\text { Analysis Type } \\
\text { Online Offline }\end{array}$ & $\begin{array}{c}\text { Coverage } \\
\text { Indoor Outdoor Both }\end{array}$ & $\begin{array}{c}\text { Object Type } \\
\text { Static Dynamic Both }\end{array}$ & $\begin{array}{c}\text { Carrying Mode } \\
\text { Wearable Handheld }\end{array}$ \\
\hline $\begin{array}{c}\text { Waist Belt } \\
\text { (Yeboah et al., } \\
\text { 2018) }\end{array}$ & 2018 & $\checkmark$ & $\checkmark$ & $\checkmark$ & $\checkmark$ \\
\hline $\begin{array}{c}\text { Deep-See } \\
\text { (Tapu et al., } \\
\text { 2017) }\end{array}$ & 2017 & $\checkmark$ & $\checkmark$ & $\checkmark$ & $\checkmark$ \\
\hline $\begin{array}{c}\text { NavGuide } \\
\text { (Patil } \text { et al., } \\
\text { 2018) }\end{array}$ & 2017 & $\checkmark$ & $\checkmark$ & $\checkmark$ & $\checkmark$ \\
\hline $\begin{array}{c}\text { Mechatronic } \\
\text { System } \\
\text { (Mancini et al., } \\
\text { 2018) }\end{array}$ & 2018 & $\checkmark$ & $\checkmark$ & $\checkmark$ & $\checkmark$ \\
\hline $\begin{array}{c}\text { Smart Glass } \\
\text { (Xiang et al., } \\
\text { 2019) }\end{array}$ & 2019 & $\sqrt{ }$ & $\sqrt{ }$ & $\sqrt{ }$ & $\sqrt{ }$ \\
\hline $\begin{array}{c}\text { Mobile Robot } \\
\text { (Nanavati et } \\
\text { al., 2018) }\end{array}$ & 2018 & $\checkmark$ & $\checkmark$ & $\sqrt{ }$ & $\checkmark$ \\
\hline $\begin{array}{c}\text { Patterned Light } \\
\text { (Cornacchia et } \\
\text { al., 2018) }\end{array}$ & 2018 & $\checkmark$ & $\checkmark$ & $\checkmark$ & $\checkmark$ \\
\hline $\begin{array}{c}\text { ISANA (Li et } \\
a l ., 2018)\end{array}$ & 2018 & $\checkmark$ & $\checkmark$ & $\checkmark$ & $\checkmark$ \\
\hline $\begin{array}{c}\text { Bbeep } \\
\text { (Kayukawa et } \\
\text { al., 2019) }\end{array}$ & 2019 & $\checkmark$ & $\checkmark$ & $\sqrt{ }$ & $\checkmark$ \\
\hline $\begin{array}{c}\text { APGR } \\
\text { (Megalingam } \\
\text { et al., 2019) }\end{array}$ & 2019 & $\checkmark$ & $\checkmark$ & $\checkmark$ & $\checkmark$ \\
\hline $\begin{array}{c}\text { Smart glass } \\
\text { (Bastomiet al., } \\
\text { 2019) }\end{array}$ & 2019 & $\checkmark$ & $\checkmark$ & $\checkmark$ & $\checkmark$ \\
\hline $\begin{array}{c}\text { Ultrasonic } \\
\text { Sensor HC- } \\
\text { SR04 (Suraj et } \\
\text { al., 2019) }\end{array}$ & 2019 & $\checkmark$ & $\bar{\checkmark}$ & $\sqrt{ }$ & $\sqrt{ }$ \\
\hline $\begin{array}{c}\text { Arduino Uno } \\
\text { (Suraj et al., } \\
\text { 2019) }\end{array}$ & 2019 & $\checkmark$ & $\checkmark$ & $\checkmark$ & $\checkmark$ \\
\hline
\end{tabular}




\begin{tabular}{|c|c|c|c|c|c|c|}
\hline $\begin{array}{c}\text { GPs Module } \\
\text { (Suraj } \text { et al., } \\
\text { 2019) }\end{array}$ & 2019 & $\sqrt{ }$ & $\checkmark$ & $\checkmark$ & & $\sqrt{ }$ \\
\hline $\begin{array}{l}\text { Buzzer (Suraj } \\
\text { et al., 2019) }\end{array}$ & 2019 & $\begin{array}{lll}\checkmark & \checkmark\end{array}$ & & & & \\
\hline $\begin{array}{c}\text { SIM28ML } \\
\text { GPS Module } \\
\text { (Suraj et al., } \\
\text { 2019) }\end{array}$ & 2019 & $\checkmark$ & $\sqrt{ }$ & $\checkmark$ & $\checkmark$ & $\checkmark$ \\
\hline $\begin{array}{c}\text { LDR } \\
\text { (Chiranjevulu } \\
\text { et al., 2020) }\end{array}$ & 2020 & $\sqrt{ }$ & $\checkmark$ & $\checkmark$ & & $\checkmark$ \\
\hline $\begin{array}{c}\text { Voice Module } \\
\text { ISD } 1820 \\
\text { (Pathak et al., } \\
\text { 2020) }\end{array}$ & 2020 & $\checkmark$ & $\sqrt{ }$ & $\checkmark$ & & $\checkmark$ \\
\hline $\begin{array}{c}\text { Smart Cap } \\
\text { (Rahman et al., } \\
\text { 2021) }\end{array}$ & 2020 & $\checkmark$ & $\checkmark$ & $\checkmark$ & $\checkmark$ & $\checkmark$ \\
\hline $\begin{array}{c}\text { Stick (Rahman } \\
\text { et al., 2021) }\end{array}$ & 2020 & $\checkmark$ & $\sqrt{ }$ & $\checkmark$ & $\checkmark$ & $\checkmark$ \\
\hline $\begin{array}{c}\text { Pi camera } \\
\text { (Suraj et al., } \\
\text { 2019) }\end{array}$ & 2019 & $\checkmark$ & $\checkmark$ & $\checkmark$ & $\checkmark$ & $\checkmark$ \\
\hline
\end{tabular}

Individuals have begun utilizing profound learning calculations for obstruction recognition over the most recent quite a while, which requests a great deal of processing power. A couple of normal contraptions are displayed in Table 8 alongside their provisions. It has been shown that most gadgets don't need a web association with work. Web access is required for contraptions that consolidate a GPS) and different applications planned for obviously obstructed people. Besides, most of the gadgets are appropriate for both indoor and outside use and can distinguish both static and dynamic obstructions. Since the start, there has been a pleasant harmony among wearable and handworked contraptions created. The practicality of proposed ways to deal with help dazzle individuals can be surveyed utilizing boundaries like force utilization, weight, cost, and ease of use. It has been found that if the gadgets are basic and depend simply on sensors for preparing, they are lightweight, powerproductive, economical, and easy to use. In any case, as more limits are added to those devices, similar to camera coordination and figuring power, they become heavier, eat up more power, and become all the more exorbitant.

UniversePG I www.universepg.com

\section{Future Direction}

In the wake of perusing the papers and surveying the gadgets constructed so far for outwardly hindered individuals, the accompanying focuses have been separated that can help scientists working in this subject later on:

- We need to add to our gadget and the assets we require, like force and cost. It is dependent upon the client to choose if they need to keep it savvy, light, and compactor spotlight on the gadget's provisions and functionalities.

- As a rule, a precise and multi-highlight gadget won't be lightweight or savvy since equipment prerequisites will increment, maybe expanding the gadget's general weight/dimensionality. A lightweight and practical arrangement will likewise be inadequate in highlights. Accordingly, accomplishing harmony among elements and assets in a continuous gadget is an assignment that scholastics may seek after as a significant future region.

- This paper discusses a range of devices that provide a variety of functions to the user, but they 
are either expensive or heavy, making them unsui-table for visually impaired people. Therefore, the time's necessity is for an answer that is savvy, lightweight, convenient, and include rich, just as fit for working progressively.

- An assortment of gadgets for the outwardly weakened has been developed, each with its own objective and answer for the issue of the outwardly weakened in some structure.

However, there is no one-stop solution designed to assist them that meets practically all of their needs.

\section{Current Research Stage}

At present, we're chipping away at a keen visually impaired stick with a camera and a Raspberry Pi. Before hand, Arduino was incorporated with the stick, yet we changed over to Raspberry Pi since we required a camera and quick handling for conveying the item discovery model. For general snag recognition, a pre-fabricated item location model, the SSD Lite Mobile Net model, has been utilized, which furnishes clients with a voice-based yield by means of Bluetooth headphones. This was just a model to perceive how the gadget capacities progressively with a sent model. We are zeroing in comprehensively on two classifications:

\section{Traffic light detection}

Outwardly hindered individuals struggle exploring uninhibitedly in the rest of the world, particularly in jam-packed regions. We will probably make traffic signal recognition for better and more secure development.

\section{Currency Denomination Detection}

An individual experiencing vision disability ought to have the option to identify the cash category, so it's not possible for anyone to swindle them, all things considered.

\section{CONCLUSION:}

The paper survey of past turns out accomplished for the outwardly disabled. We attempted to describe the beneficial technologies designed for the visually handicapped, focusing on their operation, utility, and characteristics. We attempted to make it more intuittive and justifiable by looking at the gadgets dependent on various boundaries (Table 8). The interface between the client and the framework, just as the UniversePG I www.universepg.com plan by which data is communicated to the client, are basic provisions in the improvement of an assistive gadget. Clients ought to have the option to use the thing with little exertion in case it is basic, wearable, and easy to use. Albeit a ton of exertion has been done as of late to help the outwardly impeded, there is as yet a requirement for a financially savvy arrangement with more elements to help the outwardly weakened become more proficient and autonomous. The savvy stick ought to be easy to work and low in weight, with the capacity to perform well progresssively and with high exactness. There are numerous basic smart sticks available now that are simple to use, but as technology advances, more advanced devices are being produced. These devices have a lot of features, but not all of them work in real-time. Moreover, most contraptions are substantial, making them hard to move and illogical for constant use. The emphasis ought to be on working on the precision of these gadgets, bringing down their force utilization, and making them lightweight, easy to utilize, versatile and proficient continuously. In contrast with the current gear, a solitary gadget with these components would make the existence of outwardly debilitated people more helpful.

\section{ACKNOWLEDGEMENT:}

First of all, I recognize the aid of Allah since, without Allah's help, it was unachievable. Moreover, my thanks go to the co-authors and respected professors of the Dept. of Computer Science and Engineering, Bangladesh University of Business and Technology (BUBT), for supervising me and for providing me with the appropriate assistance to finish the research work.

\section{CONFLICTS OF INTEREST:}

The authors state that they have no conflicting interests in the paper's publication.

\section{REFERENCES:}

1) Adil et al. (2020). An IoT based Voice Controlled Blind Stick to Guide Blind People. https://www.academia.edu/download/62359936/B 0901091420200313-22725-11rtxv1.pdf

2) Advanced Guide to Inception v3 on Cloud TPU. https://cloud.google.com/tpu/docs/inception-v3advanced 
3) Arduino, What is Arduino? https://www.arduino.cc/en/guide/introduction

4) Arora et al. (2019). Real time multi object detection for blind using single shot multibox detector. Wireless Personal Communications, 107(1), pp.651-661. https://doi.org/10.1007/s11277-019-06294-1

5) Asati, C., Meena, N. and Orlando, M.F., (2019). October. Development of an intelligent cane for visually impaired human subjects. In 2019 28th IEEE International Conference on Robot and Human Interactive Communication, IEEE. 1-5. https://doi.org/10.1109/RO-MAN46459.2019.89 $\underline{56328}$

6) Bashiri et al. (2018). Object detection to assist visually impaired people: A deep neural network adventure. In International Symposium on Visual Computing, Springer, pp. 500-510. https://doi.org/10.1007/978-3-030-03801-4 44

7) Bastomi et al. (2019). Object Detection and Distance Estimation Tool for Blind People Using Convolutional Methods with Stereovision. In 2019 International Symposium on Electronics and Smart Devices, pp. 1-5 https://doi.org/10.1109/ISESD.2019.8909515

8) Be My Eyes. https://www.bemyeyes.com/

9) Bhandari et al. (2021). Object detection and recognition: using deep learning to assist the visually impaired. Disability and Rehablitation: Assistive Technology, 16(3), 280-288. https://doi.org/10.1080/17483107.2019.1673834

10) Bhole, S. and Dhok, A. (2020). Deep Learning based Object Detection and Recognition Framework for the Visually Impaired. In 2020 Fourth International Conference on Computing Methodologies and Communication, 725-728. https://doi.org/10.1109/ICCMC48092.2020.ICCM C-000135

11) Biswas, M. and Whaiduzzaman, M.D. (2018). Efficient mobile cloud computing through computation offloading. Int. J. Adv. Technol, 10(2).

https://doi.org/10.4172/0976-4860.1000225

12) Biswas et al. (2021). September. An XAI Based Autism Detection: The Context behind the Detection. In International Conference on Brain Informatics, Springer, Cham. pp. 448-459. https://doi.org/10.1007/978-3-030-86993-9_40

13) Biswas et al. (2021). Indoor Navigation Support System for Patients with Neuro-degenerative Diseases. In International Conference on Brain Informatics, Springer, Cham. 411422.

https://doi.org/10.1007/978-3-030-86993-9_37

14) Bledsoe, C.W., (1997). Originators of orientation and mobility training. Foundations of orientation and mobility, pp. 580-623.

15) Blindness and vision impairment. https://www.who.int/news-room/fact-sheets/det ail/blindness-and-visual-impairment

16) Chen et al. (2019). An implementation of an intelligent assistance system for visually impaired/blind people. In 2019 IEEE International Conference on Consumer Electronics, IEEE. 1-2.

https://doi.org/10.1109/ICCE.2019.8661943

17) Chiranjevulu, D., Sanjula, D., Kumar, K.P., Murali, U.B. and Santosh, S., Intelligent Walking Stick for Blind People Using Arduino. https://doi.org/10.9790/9622-1003014245

18) Choksi, P.M., Desai, L.S. and Meghrajani, Y.K. (2021). Object Detection Using Deep Learning for Visually Impaired People in Indoor Environment. In Soft Computing and Signal Processing, Springer, Singapore. 617-625. https://doi.org/10.1007/978-981-33-6912-2_56

19) Cornacchia et al. (2018). Deep learning-based obstacle detection and classification with portable uncalibrated patterned light. IEEE Sensors Journal, 18(20), pp.8416-8425. https://doi.org/10.1109/JSEN.2018.2865306

20) Csapó, Á, Wersényi, G., Nagy, H. and Stockman, T., (2015). A survey of assistive technologies and applications for blind users on mobile platforms: a review and foundation for research. Journal on Multimodal User Interfaces, 9(4), pp.275-286. https://doi.org/10.1007/s12193-015-0182-7

21) Dakopoulos, D. and Bourbakis, N.G. (2009). Wearable obstacle avoidance electronic travel aids for blind: a survey. IEEE Transactions on Systems, Man, and Cybernetics, Part C (Applications and Reviews), 40(1), pp.25-35. https://doi.org/10.1109/TSMCC.2009.2021255 
22) Elmannai, W. and Elleithy, K. (2017). Sensorbased assistive devices for visually-impaired people: current status, challenges, and future directions. Sensors, 17(3), p.565. https://doi.org/10.3390/s17030565

23) Felix, S.M., Kumar, S. and Veeramuthu, A., (2018), A smart personal A.I. assistant for visually impaired people. In $20182^{\text {nd }}$ International Conference on Trends in Electronics and Informatics, IEEE. 1245-1250.

https://doi.org/10.1109/ICOEI.2018.8553750

24) Gbenga, D.E., Shani, A.I. and Adekunle, A.L. (2017). Smart Walking Stick for visually impaired people using ultrasonic sensors and Arduino. International Journal of Engineering and Technology, 9(5), pp.3435-3447. https://doi.org/10.21817/ijet/2017/v9i5/170905302

25) Jain, B.D., Thakur, S.M. and Suresh, K.V. (2018). Visual assistance for blind using image processing. In 2018 International Conference on Communication and Signal Processing (ICCSP) IEEE. pp. 0499-0503.

https://doi.org/10.1109/ICCSP.2018.8524251

26) Johari et al. (2020). START: Smart Stick based on TLC Algorithm in IoT Network for Visually Challenged Persons. In 2020 Fourth International Conference on I-SMAC (IoT in Social, Mobile, Analytics and Cloud) (I-SMAC), IEEE. pp. 605-610.

https://doi.org/10.1109/I-SMAC49090.2020.924

$\underline{3517}$

27) Kammoun et al. (2011). Toward a better guidance in wearable electronic orientation aids. In IFIP Conference on Human-Computer Interaction, Springer, Berlin, Heidelberg. 624627.

https://doi.org/10.1007/978-3-642-23768-3_98

28) Kayukawa et al. (2019). May. Bbeep: A sonic collision avoidance system for blind travelers and nearby pedestrians. In Proceedings of the 2019 CHI Conference on Human Factors in Computing Systems, pp. 1-12. https://doi.org/10.1145/3290605.3300282

29) KNFB Reader. https://nfb.org/programs-services/knfb-reader

30) Krishnan, A., Nishanth, N. and Anandkumar, K.M., (2016). December. Autonomous walking stick for the blind using echolocation and image processing. In $20162^{\text {nd }}$ International Conference on Contemporary Computing and Informatics (IC3I), IEEE, pp. 13-16. https://doi.org/10.1109/IC3I.2016.7917927

31) Kumar, A., Reddy, S.S.S. and Kulkarni, V., (2019). An object detection technique for blind people in real-time using deep neural network. In 2019 Fifth International Conference on Image Information Processing, IEEE. 292-297. https://doi.org/10.1109/ICIIP47207.2019.8985965

32) Kunta, V., Tuniki, C. and Sairam, U. (2020). Multi-functional blind stick for visually impaired people. In $20205^{\text {th }}$ International Conference on Communication and Electronics Systems (ICCES) IEEE. pp. 895-899.

https://doi.org/10.1109/ICCES48766.2020.9137870

33) Li et al. (2018). Vision-based mobile indoor assistive navigation aid for blind people. IEEE transactions on mobile computing, 18(3), pp. 702-714. https://doi.org/10.1109/TMC.2018.2842751

34) LookTel, what is LookTel? http://www.looktel.com/

35) Mahbub et al., (2021). COVID-19 Detection Using Chest X-Ray Images with a RegNet Structured Deep Learning Model. In International Conference on Applied Intelligence and Informatics, Springer, Cham. pp. 358-370. https://doi.org/10.1007/978-3-030-82269-9_28

36) Mahesh et al. (2021). February. CICERONE-A Real Time Object Detection for Visually Impaired People. In IOP Conference Series: Materials Science and Engineering, IOP Publishing. 1085(1), p. 012006. https://doi.org/10.1088/1757-899X/1085/1/0120 06

37) Mamun AMA, Islam T, Siam MMS, and Kabir ME. (2020). Development of smart librarian with the virtual assistant (PRIMO), Aust. J. Eng. Innov. Technol., 2(4), 54-65. https://doi.org/10.34104/ajeit.020.054065

38) Mancini, A., Frontoni, E. and Zingaretti, P. (2018). Mechatronic system to help visually impaired users during walking and running. IEEE transactions on intelligent transportation systems, 19(2), pp.649-660. https://doi.org/10.1109/TITS.2017.2780621 
39) Megalingam, R.K., Vishnu, S., Sasikumar, V. and Sreekumar, S., (2019). Autonomous path guiding robot for visually impaired people. In Cognitive Informatics and Soft Computing, Springer, Singapore. pp. 257-266.

https://doi.org/10.1007/978-981-13-0617-4_25

40) Moharkar, L., Varun, S., Patil, A. and Pal, A., (2020). A scene perception system for visually impaired based on object detection and classification using CNN. In ITM Web of Conferences EDP Sciences. 32, p. 03039.

https://doi.org/10.1051/itmconf/20203203039

41) Mule, N., Patil, D.D. and Chavhan, Y.D., (2020). In-house Object Detection System for Visually Impaired. International J. of Future Generation Communication and Networking, 13(4), pp.4919-4926.

42) Nabiha, S., Aziz, A., Wadood, M.A., Junaid, M. and Kumar, B.K. (2020). A.I. Based Assistance for Visually Impaired People Using TTS (text to speech).

http://www.jctjournal.com/gallery/25-may2020. pdf

43) Nanavati, A., Tan, X.Z. and Steinfeld, A. (2018). March. Coupled indoor navigation for people who are blind. In Companion of the 2018 ACM/IEEE International Conference on Human-Robot Interaction, pp. 201-202. https://doi.org/10.1145/3173386.3176976

44) Parikh, N., Shah, I. and Vahora, S. (2018). Android smartphone based visual object recognition for visually impaired using deep Learning. In 2018 International Conference on Communication and Signal Processing, IEEE. pp.0420-0425.

https://doi.org/10.1109/ICCSP.2018.8524493

45) Patel et al. (2018). Multi sensor-based object detection in indoor environment for visually impaired people. In 2018 Second International Conference on Intelligent Computing and Control Systems (ICICCS), IEEE. pp. 1-4. https://doi.org/10.1109/ICCONS.2018.8663016

46) Pathak, A., Adil, M., Rafa, T.S., Ferdoush, J. and Mahmud, A. (2020). An IoT based Voice Controlled Blind Stick to Guide Blind People. https://www.academia.edu/download/65610658/B 09010914.pdf

UniversePG I www.universepg.com
47) Patil, K., Jawadwala, Q. and Shu, F.C. (2018). Design and construction of electronic aid for visually impaired people. IEEE Transactions on Human-Machine Systems, 48(2), pp.172-182. https://doi.org/10.1109/THMS.2018.2799588

48) Proulx, M.J., de Sousa, A.A. and Brown, D.J. (2016). Other ways of seeing: from behavior to neural mechanisms in the online "visual" control of action with sensory substitution. Restorative neurology and neuroscience, 34(1), 29-44. https://doi.org/10.3233/RNN-150541

49) Rahman et al. (2021). The architectural design of smart blind assistant using IoT with deep learning paradigm. Internet of Things, 13, $\mathrm{p}$. 100344. https://doi.org/10.1016/j.iot.2020.100344

50) Rahman et al. (2020). IoT Based Smart Assistant for Blind Person and Smart Home Using the Bengali Language. SN Computer Science, 1(5), pp.1-13. https://doi.org/10.1007/s42979-020-00317-6

51) Raspberry Pi, What is Raspberry Pi? https://www.raspberrypi.org/help/what-\%20is-araspberry-pi/ (Accessed on 13 August 2021).

52) Ray, B., Saha, K.K. and Rahman, M.M. (2020). December. User Perspective on Usages and Privacy of eHealth Systems in Bangladesh: A Dhaka based Survey. In 2020 IEEE Asia Pacific Conference on Computer Science and Data Engineering (CSDE), IEEE. pp. 1-5. https://doi.org/10.1109/CSDE50874.2020.941159

53) Say Text Apps for blind and visually impaired people. Accessed on 8 August 2021.

http://etalinq.com/en/say-text-apps-for-blind-andvisually-impaired-people/

54) Soell, H. (2013). Helmut Schmidt: Pioneer of International Economic and Financial Cooperation. Springer Sci. \& Business Media. 20. https://www.springer.com/gp/book/97833190386 $\underline{74}$

55) Subbiah et al. (2019). Smart Cane for Visually Impaired Based On IOT. In $20193^{\text {rd }}$ International Conference on Computing and Communications Technologies, IEEE. pp. 50-53. https://doi.org/10.1109/ICCCT2.2019.8824893

56) Sumathy et al. (2021). Smart Guidance System for Blind with Wireless Voice Playback. In IOP 
Conference Series: Materials Science and Engineering, IOP Publishing. 1012(1), 012045. https://doi.org/10.1088/1757-899X/1012/1/0120 45

57) Suraj et al. (2019). April. Obstacle Detection for the Visually Impaired Using Arduino. In $20193^{\text {rd }}$ International Conference on Trends in Electronics and Informatics, IEEE. 260-265. https://doi.org/10.1109/ICOEI.2019.8862635

58) TapTapSee, (2021). https://taptapseeapp.com/

59) Tapu, R., Mocanu, B. and Zaharia, T. (2017). DEEP-SEE: Joint object detection, tracking and recognition with application to visually impairred navigational assistance. Sensors, 17(11), p. 2473.

https://doi.org/10.3390/s17112473

60) Vaidya, S., Shah, N. and Shankarmani, R. (2020). May. Real-Time Object Detection for Visually Challenged People. In $20204^{\text {th }}$ International Conference on Intelligent Computing and Control Systems, IEEE. pp.311-316. https://doi.org/10.1109/ICICCS48265.2020.9121085
61) Xiang, K., Wang, K., Fei, L. and Yang, K., (2019). May. Store sign text recognition for wearable navigation assistance system. In $J$. of Physics: Conference Series, IOP Publishing. 1229(1), p. 012070.

https://doi.org/10.1088/1742-6596/1229/1/012070

62) Yeboah, M.O., Kuada et al. (2018). August. Design of a Voice Guided Ultrasonic Spectacle and Waist Belt with GPS for the Visually Impaired. In 2018 IEEE $7^{\text {th }}$ International Conference on Adaptive Science \& Technology (ICAST), IEEE. pp. 1-7.

https://doi.org/10.1109/ICASTECH.2018.8507057

63) Yohannes, E., Lin, P., Lin, C.Y. and Shih, T.K., (2020). Robot Eye: Automatic Object Detection and Recognition Using Deep Attention Network to Assist Blind People. In 2020 International Conference on Pervasive Artificial Intelligence (ICPAI), IEEE. pp. 152-157. https://doi.org/10.1109/ICPAI51961.2020.00036

Citation: Hassan MK, Hassan MR, Ahmed MMT, Sabbir MSA, Ahmed MS, and Biswas M.(2021). A survey on an intelligent system for persons with visual disabilities. Aust. J. Eng. Innov. Technol., 3(6), 97-118. https://doi.org/10.34104/ajeit.021.0970118 @) (i) 